\title{
Property Valuation Techniques
}


Macmillan Building and Surveying Series

Series Editor: Ivor H. Seeley

Emeritus Professor, Nottingham Polytechnic

Advanced Building Management, second edition Ivor H. Seeley

Advanced Valuation Diane Butler and David Richmond

An Introduction to Building Services Christopher A. Howard

Applied Valuation Diane Butler

Asset Valuation Michael Rayner

Building Economics, third edition Ivor H. Seeley

Building Maintenance, second edition Ivor $\mathrm{H}$. Seeley

Building Procurement Alan E. Turner

Building Quantities Explained, fourth edition Ivor $\mathrm{H}$. Seeley

Building Surveys, Reports and Dilapidations Ivor H. Seeley

Building Technology, third edition Ivor H. Seeley

Civil Engineering Quantities, fourth edition Ivor H. Seeley

Civil Engineering Specification, second edition Ivor $\mathrm{H}$. Seeley

Computers and Quantity Surveyors A. J. Smith

Contract Planning and Contractual Procedures B. Cooke

Contract Planning Case Studies B. Cooke

Development Site Evaluation N. P. Taylor

Environmental Science in Building, second edition R. McMullan

Housing Associations Helen Cope

Introduction to Valuation D. Richmond

Marketing and Property People Owen Bevan

Principles of Property Investment and Pricing W. D. Fraser

Property Valuation Techniques David Isaac and Terry Steley

Quality Assurance in Building Alan Griffith

Quality Surveying Practice Ivor H. Seeley

Structural Detailing, second edition P. Newton

Urban Land Economics and Public Policy, fourth edition P. N. Balchin,

J. L. Kieve and G. H. Bull

Urban Renewal - Theory and Practice Chris Couch

1980 JCT Standard Form of Building Contract, second edition R. F.

Fellows

\section{Series Standing Order}

If you would like to receive future titles in this series as they are

published, you can make use of our standing order facility. To place a standing order please contact your bookseller or, in case of difficulty, write to us at the address below with your name and address and the name of the series. Please state with which title you wish to begin your standing order. (If you live outside the United Kingdom we may not have the rights for your area, in which case we will forward your order to the publisher concerned.)

Customer Services Department, Macmillan Distribution Ltd Houndmills, Basingstoke, Hampshire, RG21 2XS, England. 


\title{
Property Valuation Techniques
}

\author{
David Isaac and Terry Steley
}

School of Surveying, Thames Polytechnic

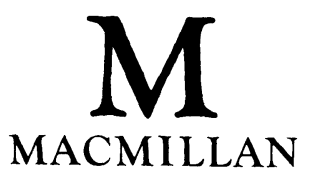


(C) David Isaac and Terry Steley 1991

All rights reserved. No reproduction, copy or transmission of this publication may be made without written permission.

No paragraph of this publication may be reproduced, copied or transmitted save with written permission or in accordance with the provisions of the Copyright, Designs and Patents Act 1988 or under the terms of any licence permitting limited copying issued by the Copyright Licensing Agency, 33 - 4 Alfred Place, London WC1E 7DP.

Any person who does any unauthorised act in relation to this publication may be liable to criminal prosecution and civil claims for damages.

First edition 1991

Published by

MACMILLAN EDUCATION LTD

Houndmills, Basingstoke, Hampshire RG21 2XS

and London

Companies and representatives

throughout the world

ISBN 978-0-333-47151-7

ISBN 978-1-349-21573-7 (eBook)

DOI $10.1007 / 978-1-349-21573-7$

A catalogue record for this book is available from the British Library 


\section{Contents}

Preface

Acknowledgements

vii

viii

1 Introduction 1

A discussion of new approaches to valuation methods

2 Traditional Method of Investment Valuation

16

A summary of the traditional approaches to valuation methods

3 Discounted Cash Flow

The use of a cash flow approach. How cash flows are calculated. The application of cash flows in the residual valuation. Net Present Value and Internal Rate of Return. Comparison of projects using DCF and IRR. The detailed calculation of IRR. The benefits of calculating NPV as against IRR. The 'target' yield

4 Interest Rates and Yields

Nominal rates of interest. How the stock market works; the changes in price and yield. How a yield rate is calculated.

Risk, inflation, how to assess the 'target' yield

\section{Equated Yields}

The calculation of the IRR with growth. The use of the equated yield. Donaldson's Tables and the calculation of the equated yield

\section{Hardcore Method}

The use of the method. The use of a layer approach as opposed to a block approach to property valuation. How risk is incorporated in the model

\section{Equivalent Yields}

The term and reversion in traditional methods. How the equivalent yield copes with the overall yield 
8 Equated Rents

Equated and constant rents. Use of this approach.

Donaldson's and Rose's Tables, and how they can be applied

9 Rent Payments

The problems of adjusting for rent income in different periods. Adjusting for rent being quarterly in advance

10 Taxation

Valuations, taking taxation into account

11 Risk

Problems of risk

12 Problems of Leasehold Valuations

Problems of leaseholds: short leaseholds and sinking funds

13 Development Valuations and the Cash Flow Approach

The residual valuation and the cash flow approach. The ability to change inputs over time and introduce accuracy into the calculations

14 Computer Models and the Use of Spreadsheets

The use of computer models. Examples of spreadsheet models which calculate equated yields

15 Financial Appraisal Techniques

The use of DCF in other areas. How stockbrokers and financial analysts value companies. The use of the $P / E$ ratio

16 New Directions

Portfolio theory and the application of financial theory to property investments. Depreciation of property assets. Developments in research into methods 


\section{Preface}

This book is intended as an introduction to alternative approaches to real property valuation methods. It should be made clear at the beginning that we are talking about property appraisal which involves the initial valuation of property and subsequent analysis. The book outlines the traditional valuation and a critique of the approach, but does not dwell on this. Its aim is to extend considerations of alternative approaches to valuation and analysis of property investments.

The book will be useful for a number of different groups, including students, practitioners and also those whose background is not in the property field. For the student, it extends the basic texts and updates them to allow for developments in valuation techniques. It is thus an important book for those looking to develop valuation methods at the second and third year undergraduate level and also as a basis for postgraduate work. For the practitioner, the book is not intended to be too theoretical but to show applications of the different techniques in practice; as such, it is a useful reference book, and essential for the practitioner intending to keep abreast of developments in techniques. Finally, it is useful for professionals associated with property who may not be trained surveyors; this is because the book looks outwards from the property sector and tries to relate the techniques of property appraisal to those used in other sectors by other types of professional. The approach is based on practice and learning situations and, where possible, each chapter is made to be self-contained to aid reference, and thus there is some repetition of content; however, cross-references are included where a greater amount of background to any situation is required. The treatment is intended to parallel moves within the profession to take a less insular view of property appraisal and provide solutions which are acceptable and understandable to clients and professionals from other backgrounds; it aims to take the reader into new avenues of thought and discussion rather than down a route of more complex mathematical solutions, and looks to generate ideas about concepts rather than formulae. Where formulae are included, every effort has been made to simplify them and present them in a simple and usable way.

The book has a chapter on computer applications but does not just pay lip service to relating the appraisals to computer usage. The layout of the valuations and formulae, as well as adding clarity, in many cases provides a structure from which the reader can construct a spreadsheet calculation, and the layout assists in some detail as to its arrangement. 
Finally, the book aims to link the reader more readily to other areas of financial analysis. It opens up for the reader the wider role of investment and business, and provides comparisons with other business investments. This approach is important for a number of reasons: property valuation and analysis is not the exclusive domain of property valuation professionals but is shared with other surveyors, other professions involved in investment and asset management and investors, developers, landholders and corporate clients with property assets. The book aims to demystify the techniques and make them usable, in order to develop the concepts and practice of appraising property assets.

Chapter 1 is an introduction and serves as a critique of the traditional approaches to property valuation, while chapter 2 is important as an explanation of the traditional method. Readers conversant with the traditional method may choose to miss out chapter 2; conversely, those readers who may find the concepts in chapter 1 difficult initially should refer first to chapter 2 .

We would like to thank Professor Ivor Seeley, the Series Editor, for his helpful advice in the preparation of this book; also Professor David Wills and staff at the School of Surveying, Thames Polytechnic for their help and support.

Thames Polytechnic

School of Surveying

December 1990
David Isaac

Terry Steley

\section{ACKNOWLEDGEMENTS}

The authors and publishers wish to thank the following for permission to use copyright material:

Financial Times for extracts from Financial Times, 10th July, 1990.

Every effort has been made to trace all the copyright holders, but if any have been inadvertently overlooked the publishers will be pleased to make the necessary arrangement at the first opportunity. 